\title{
Field efficacy of new generation insecticides for the management of spotted pod borer, Maruca vitrata (Fab.) in cowpea
}

\author{
B.K. Singh ${ }^{1 *}$, Rakesh Pandey ${ }^{1}$, A.K. Singh ${ }^{1}$, M.K. Mishra ${ }^{1}$, S.K. Singh ${ }^{1}$ and R.P. Gupta ${ }^{2}$
}

${ }^{1}$ Department of Entomology, Banda University of Agriculture and Technology, Banda (U.P.) India

${ }^{2}$ National Horticultural Research and Development Foundation, Nasik (M.S.) India

\section{ARITCLE INFO}

Received : 01.02 .2020

Revised : 18.02 .2020

Accepted : 03.03 .2020

\section{KEY WORDS :}

Cowpea, New generation insecticides, Management, Maruca vitrata
*Corresponding author:

Email : bhupendrakumarsingh@gmail.

com

\begin{abstract}
The spotted pod borer, Maruca vitrata (Fab.) causes significant damage by attacking pods in cowpea. The aim of this study was to evaluate the field efficacy of new generation insecticides against spotted pod borer. Field experiments were conducted at Regional Research Station, Nasik (Maharashtra) on cowpea during Kharif, 2009 and 2010. Among the new generations tested, flubendiamide 20 WG @ $1.0 \mathrm{~g} / 1$ (4.79\%) was observed significantly higher, in reducing the damage caused by the spotted pod borer in cowpea, on number basis followed by indoxacarb 14.5SC @ $0.5 \mathrm{ml} / 1$ ( $7.99 \%)$ and spinosad $45 \mathrm{SC}$ @ $0.3 \mathrm{ml} / 1(8.70 \%)$. The highest marketable yield $(91.49 \mathrm{q} / \mathrm{ha})$ was recorded in flubendiamide 20WG@1.0 g/l followed by spinosad $45 \mathrm{SC} @ 0.3 \mathrm{ml} / \mathrm{l}(91.39 \mathrm{q} / \mathrm{ha})$. However, the maximum cost benefit ratio (1:3.2) was recorded in thiodicarb 75 WP @ 1 g/l followed by indoxacarb $14.5 \mathrm{SC} @ 0.5 \mathrm{ml} / \mathrm{l}$ (1:2.3), spinosad $45 \mathrm{SC} @ 0.3 \mathrm{ml} / 1$ (1:1.9), emamectin benzoate 5 SG @ 0.5 g/l (1:1.3), flubendiamide 20WG @ 1.0 g/l (1:1.1). On the basis of efficacy, flubendiamide 20WG @ $1.0 \mathrm{~g} / \mathrm{l}$ was observed to be very effective against Maruca vitrata in cowpea followed by indoxacarb 14.5 SC @ $0.5 \mathrm{ml} / \mathrm{l}$ and spinosad 45 SC @ $0.3 \mathrm{ml} / \mathrm{l}$.
\end{abstract}

How to view point the article : Singh, B.K., Pandey, Rakesh, Singh, A.K., Mishra, M.K., Singh, S.K. and Gupta, R.P. (2020). Field efficacy of new generation insecticides for the management of spotted pod borer, Maruca vitrata (Fab.) in cowpea. Internat. J. Plant Protec., 13(1) : 36-39, DOI : 10.15740/HAS/IJPP/13.1/36-39, Copyright@ 2020: Hind Agri-Horticultural Society. 